The $B D J$ News section accepts items that include general news, latest research and diary events that interest our

readers. Press releases or articles may be edited, and should include a colour photograph if possible. Please direct your correspondence to the News Editor,

Arveen Bajaj at the BDJ, The Macmillan

Building, 4 Crinan Street, London N1 9XW

or by email to bdj@bda.org

\section{Programme for medical students}

King's College London Dental Institute is to admit its first cohort to a threeyear dental programme for medical graduates this September. Two years ago the Dental Institute introduced a four-year programme for graduates with a biomedical background.

An increasing number of these graduate applications are medically qualified. These graduates intend to pursue a career in maxillofacial surgery or oral medicine and for 2007 entry this number reached 21. As a consequence of this, the Institute applied for, and was awarded, seven places for medical graduates who will be able to pursue a three-year dental programme.

$\mathrm{Dr}$ Lyndon Cabot, Director of Admissions at King's College London commented, 'This is excellent news. The quality of the applicants to our four-year programme is very good indeed and the large number of medical graduates in this applicant pool made for very fierce competition. Being able to remove the best of this group to this exciting new three-year programme has helped enormously in graduate selection.'

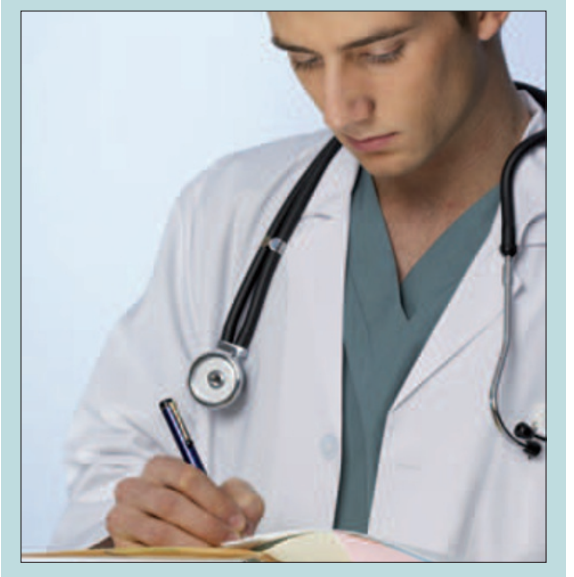

\title{
Dental school making progress
}

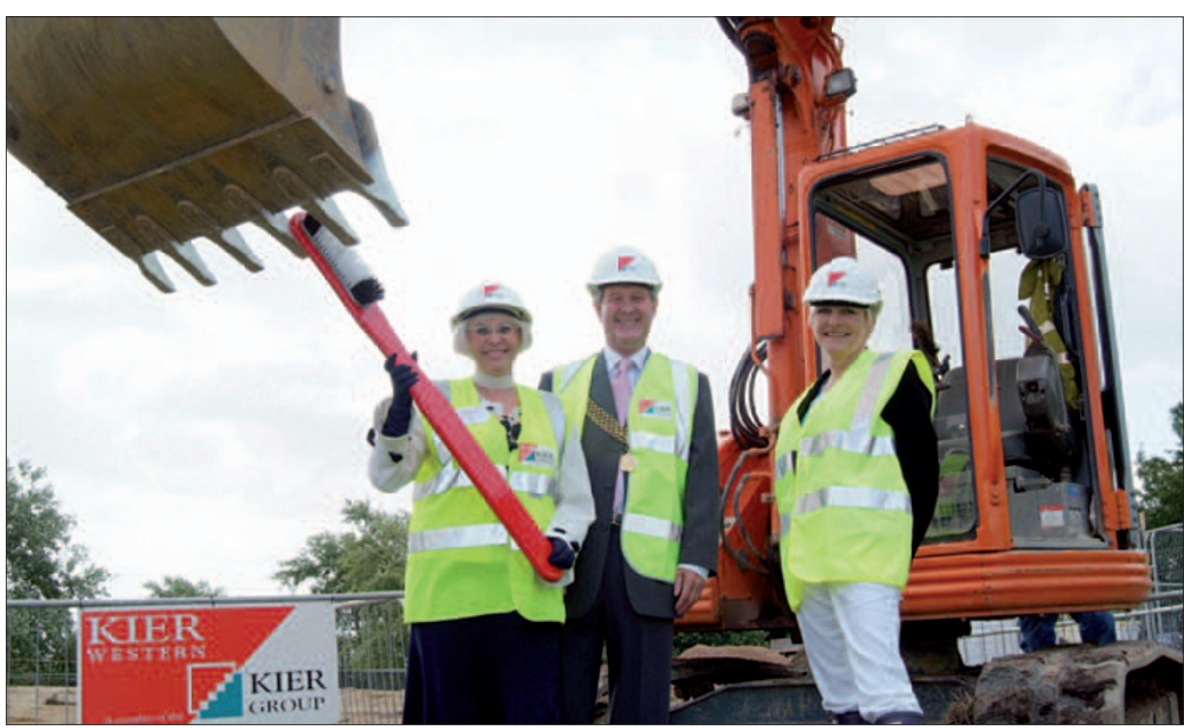

The Peninsula Dental School in Plymouth has taken one step nearer to fruition with the official turf cutting ceremony held earlier this month. The turf cutting was carried out by Professor Liz Kay, Dean of the School. She cut the first turf using a mechanical digger with white 'teeth', complete with a giant toothbrush.

The Peninsula Dental School will welcome its first 64 students to its sites in Exeter, Plymouth and Truro in September. It is the first new dental school for 40 years, and was awarded 64 of the 100 student places on offer from government when the contracts were announced last January.

The facility about to be built in Devonport will be the largest of its sites and will provide state-ofthe-art teaching and experience based training for dental students, as well as community dental provision for the city of Plymouth. Pictured from left to right are Lady Mayoress of Plymouth Mrs Diane James, Lord Mayor of Plymouth Cllr. David James with Professor Liz Kay, Dean, Peninsula Dental School.

\section{Periodontal \\ bacteria found in amniotic fluid}

A study has found bacteria commonly present in the mouth and associated with periodontal diseases in the amniotic fluid of some pregnant women. The study, which evaluated 26 pregnant women with a diagnosis of threatened premature labour, found the presence of periodontal bacteria Porphyromonas gingivalis in both the oral cavity and amniotic fluid in $30 \%$ of the women.
As the liquid that surrounds an unborn baby during pregnancy, any disruptions in the amniotic fluid, such as a bacterial infection, could potentially be dangerous to both the mother and baby.

Study author Gorge Gamonal, Faculty of Dentistry, University of Chile explained, 'We know that there are many reasons a woman can be diagnosed with threatened premature labour, including bacterial infection. Past research has shown a relationship between adverse pregnancy outcomes and periodontal disease.' The study appears in the Journal of Periodontology (2007; 78: 1249-1255). 


\section{Poster prize winners success}

Four winners received awards for the best presentations in the annual East-

ern Region Hospitals Junior Papers Day at the British School of Racing in

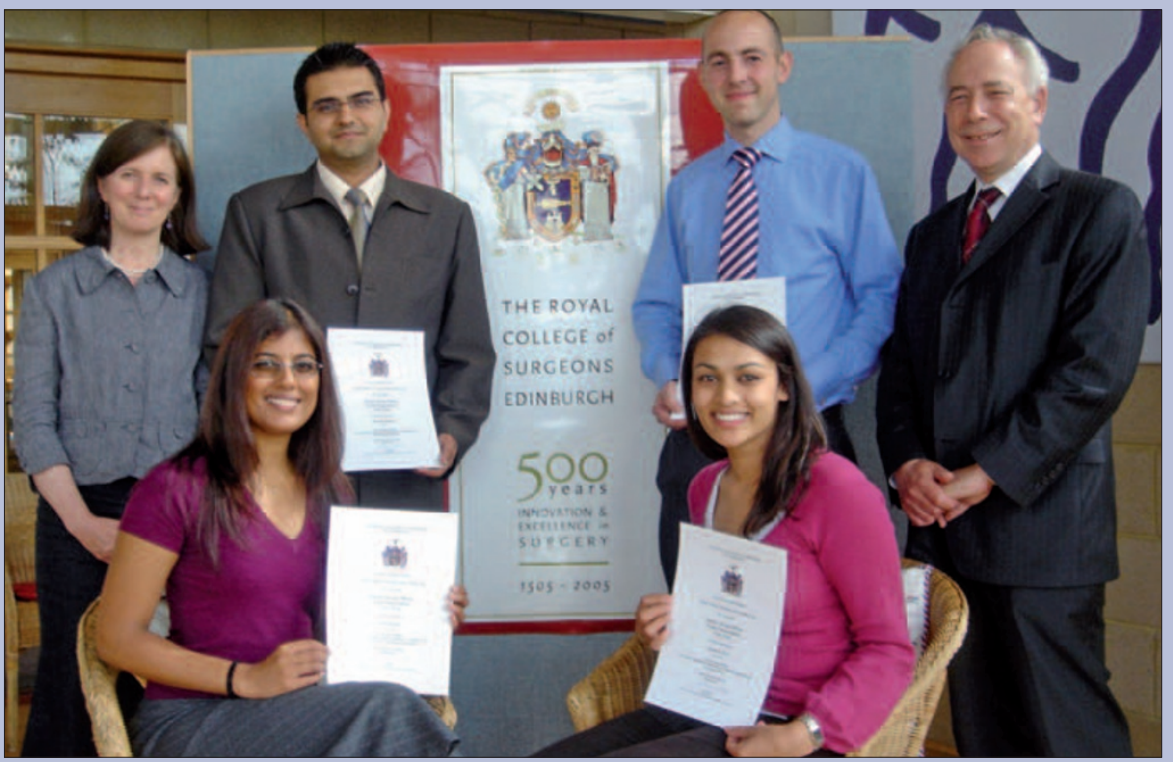

Newmarket recently. The prize winners were Oliver Mitchell, Senior House Officer (SHO) from Peterborough, for his presentation on Intermaxillary fixation screws - multiple uses, Kushal Gadhia, SHO from Luton and Dunstable, for his presentation on An audit reviewing the prescription of analgesia to maxillofacial patients, Aarti Sodha, SHO from Luton and Dunstable, for her presentation on An audit to review current practice in consent form completion for third molar extraction, and Shammi Rouf, SHO from Norfolk and Norwich University Hospital, for her poster entitled An audit of antibiotic prescribing of oral and maxillofacial in-patient TTOs.

Pictured standing from left to right are the day's organiser and consultant maxillofacial surgeon Sharon Prince, Kushal Gadhia, Oliver Mitchell and Dr Howard Moody, Vice Dean of the Faculty of Dental Surgery, Royal College of Surgeons of Edinburgh; seated left to right are Aarti Sodha and Shammi Rouf.

\section{New-look council}

The GDC has agreed the composition of the twelve registrant members of a newlook, smaller, fully appointed Council, expected to be in place in 2008. It will consist of eight dentists and four dental care professionals. Council members will not be appointed as representatives of any particular group, and should have the skills for the job.

GDC President Hew Mathewson commented, 'I am aware that some believe losing the right to elect members means they will have little say in the regulation of their profession. This is not so. The Council will always want to consult on key policy decisions and modernisation initiatives. In doing so, it must weigh up the views and expectations of patients, the public and the profession.'

He added that the Council would be encouraging a wide variety of registrants to apply to be Council members over the next year or so and would consider the different ways of involving all professional groups and individuals across the Council's work.

Members of the new Council will be appointed by the Appointments Commission, within parameters set by the GDC.

The Council will now draw up the job profile and person specifications for these positions ensuring that consideration is given to particular areas of expertise required.

\section{Highest standards recognised}

The Maurice Wohl General Dental Practice Centre recently celebrated another year's success by awarding prizes for excellence to three final year students. Prizes are awarded to students who fulfil the highest standards in all aspects of the Centre's teaching. These include treatment planning and supporting clinical proficiencies, personal inter-relationship skills with staff and patients, effective team facilitation including close support four-handed dentistry, and professional attitude and outlook. The final selection of winners was decided upon by dental nurses, sen- ior staff and the director, Brian Davies.

The Maurice Wohl GDP Centre is part of the Department of Primary Care Dentistry at the GKT Dental Institute, where final year students work in an adult general practice environment to perfect their clinical skills and learn successful team work and aspects of practice management.

Students have a caseload of adult patients and work in conjunction with qualified and trainee dental nurses in each of the Centre's eight surgeries under the supervision of an experienced dental practitioner.

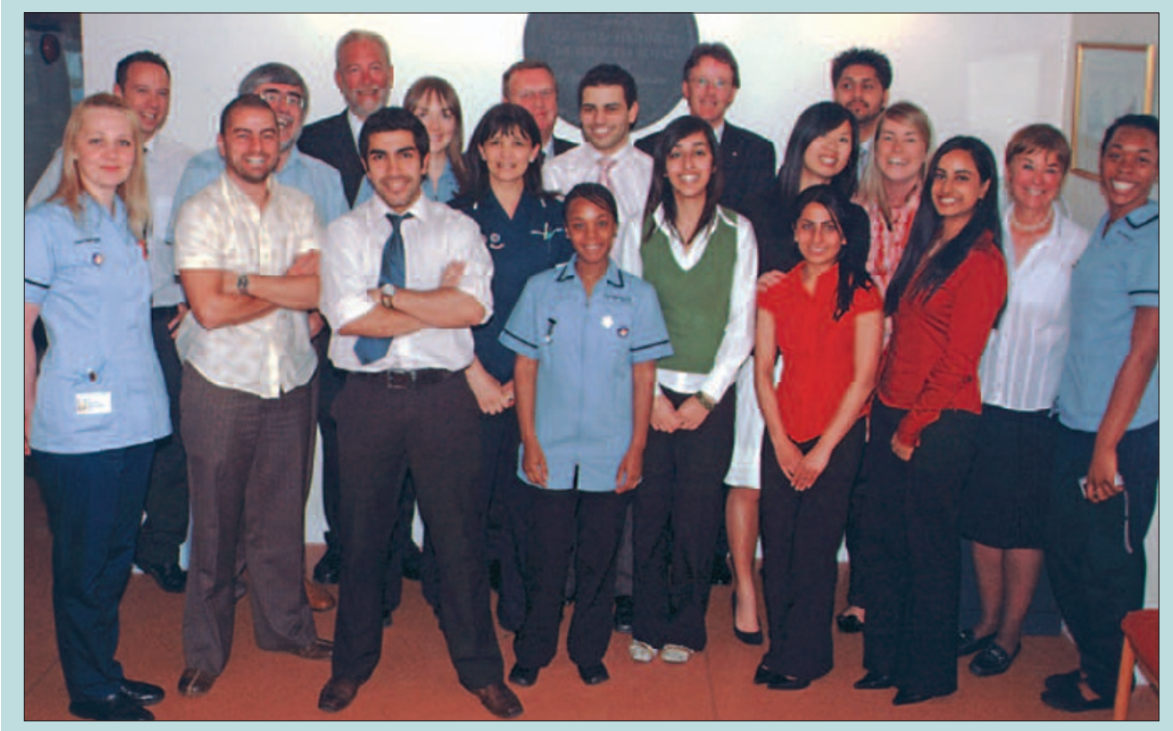




\section{Clinical and research prizes awarded}

The British Society for Restorative Dentistry awards two annual prizes for

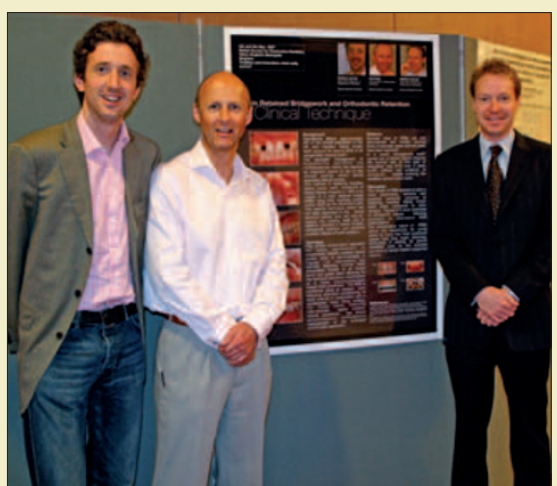

Left to right, Matthew Jerreat, Paul King and Matthew Garrett postgraduate poster presentations, one for a research-based project and the other for a clinical case report.

At this year's spring scientific meeting in Brighton, the case report prize was presented to Matthew Garrett, Matthew Jerreat and Paul King of Bristol Dental Hospital \&t School, for their description of a clinical technique to replace missing upper lateral incisor teeth using resin-retained bridgework.

The research prize was awarded to Paul Franklin from Leeds Dental Institute for his project comparing tooth contacts between programmed and average-value settings on a fully adjustable articulator.

\section{A ball of a time for VDPs}

The theme was masquerade at this year's annual VDP Ball sponsored by Integrated Dental Holdings (IDH). The ball saw guests don Venetian masks upon arrival at the lavish drinks reception before descending to the ballroom where artists, performances and medieval music entertained them throughout the evening.

Acts included six masquerade ball dancers who danced to Phantom of the Opera in traditional costume and masks and later returned to help the Salsa dancers with some audience participation.

The event was held at the BDA Conference in Harrogate earlier this year and three lucky guests received winning gold stars inside their masks and each won prizes. First prize was a state-of-the-art digital camera, with an

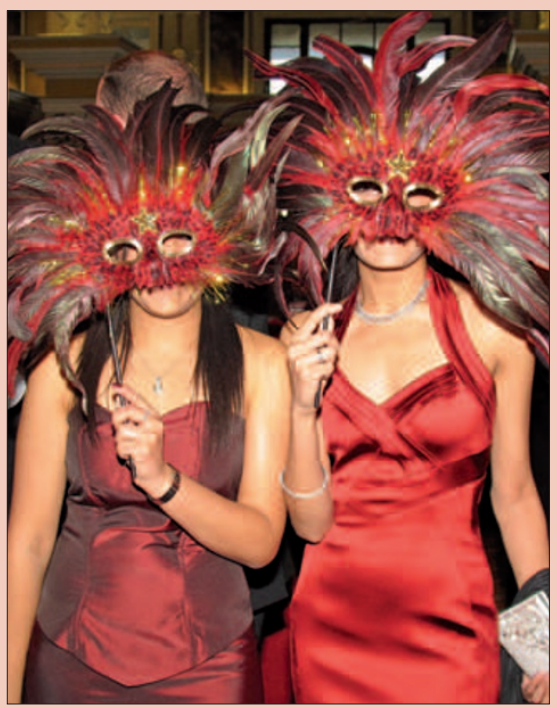

iPod Nano as second prize and an iPod Shuffle as the third prize.

\section{New Vice Dean elected}

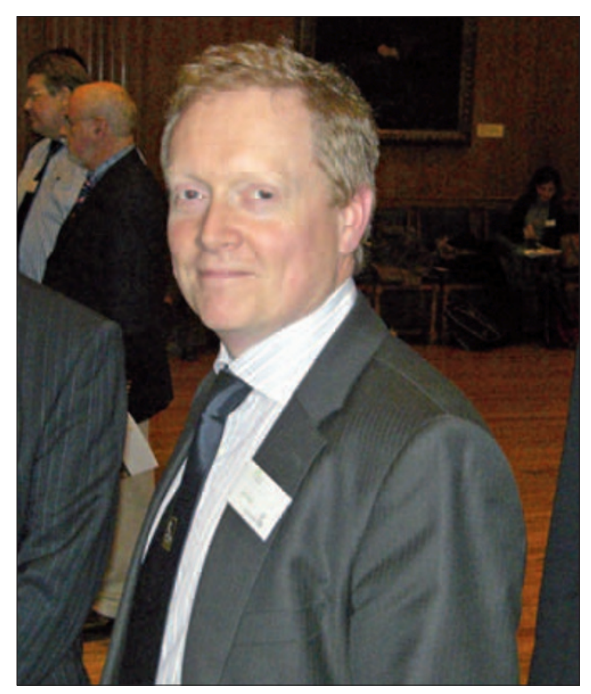

The Faculty of General Dental Practice (UK) has announced the election of Ian Wood as its Vice Dean. Ian has worked in general dental practice since he qualified in 1979, and is the owner of a five-surgery practice in Manchester.

He was elected to the FGDP(UK) Board in 2000 and has held several positions within the Faculty, including MFGDP(UK) tutor and Director of the Faculty's NorthWest division. He currently serves as Chair of the Credit Transfer Committee. In 2004, Ian became the first Course Director for the FGDP(UK)'s Diploma in Restorative Dentistry, an innovative programme recognised as offering a high standard of training and mentoring in the field. Ian was awarded the Fellowship of the Faculty in 2005, and recently completed an MPhil in operative dentistry from Manchester University.

Ian joins Andy Hadden, who has also been elected to serve a second year as Vice Dean. 


\section{DIARY}

\section{September}

4th Annual Meeting of the European Society of Esthetic Dentistry Date: 21-23 September 2007

Venue: Vienna, Austria

Email: iris.bobal@media.co.at

www.escdonline.eu

\section{American Dental Association}

Date: 27-30 September 2007

Venue: The Moscone Center,

San Francisco, USA

www.ada.org

\section{October}

British Society of Oral Implantology

Date: 6 October 2007

Venue: The University of Glamorgan

Email: support@BSOl.org

www.BSOl.org

Oral Cancer: Challenges and Solutions

Date: 6 October 2007

Venue: UCL Eastman Dental Institute,

London

www.eastman.ucl.ac.uk

BDTA Dental Showcase

Date: 18-20 October 2007

Venue: NEC Birmingham

Tel: 01494789959

www.dentalshowcase.com

North of Scotland BDA Conference and Ceilidh

Date: 20 October 2007

Venue: Apex Hotel and Spa, Dundee

Email: bdascotland@hotmail.com

Tel: +44 (0)1382635964

Annual meeting of the Society of Craniofacial Genetics \&t American Society of Human Genetics

Date: 23 October 2007

Venue: Convention Center, San Diego,

California, USA

www.craniofacialgenetics.org

FDI Annual World Dental Congress

Date: 24-27 October 2007

Venue: Dubai, UAE

Email:congress@fdiworldental.org

www.fdiworldental.org

\section{Fake toothpaste found}

Consumers are being warned that a small quantity of fake toothpaste, falsely packaged and labelled as Sensodyne, could be toxic to young children and anyone with impaired liver or kidney function. The packs, which have dual language Arabic and English text on them, have been found in local market stalls and discount shops in the UK.

GlaxoSmithKline Consumer Healthcare (GSK) markets Sensodyne with English-only packaging in the UK. The counterfeit product is contained in a 50 $\mathrm{ml}$ tube, a tube size that is not sold in the UK by GSK.

Testing of the counterfeit product has confirmed that it contains diethylene glycol (DEG). GlaxoSmithKline does not use DEG as an ingredient in the toothpaste it manufactures anywhere in the world and has said it could be toxic to young children and anyone with impaired liver or kidney function.

The fake packs are labelled as Sensodyne Original and Sensodyne Mint toothpaste and Trading Standards has seized around 140 tubes to date.

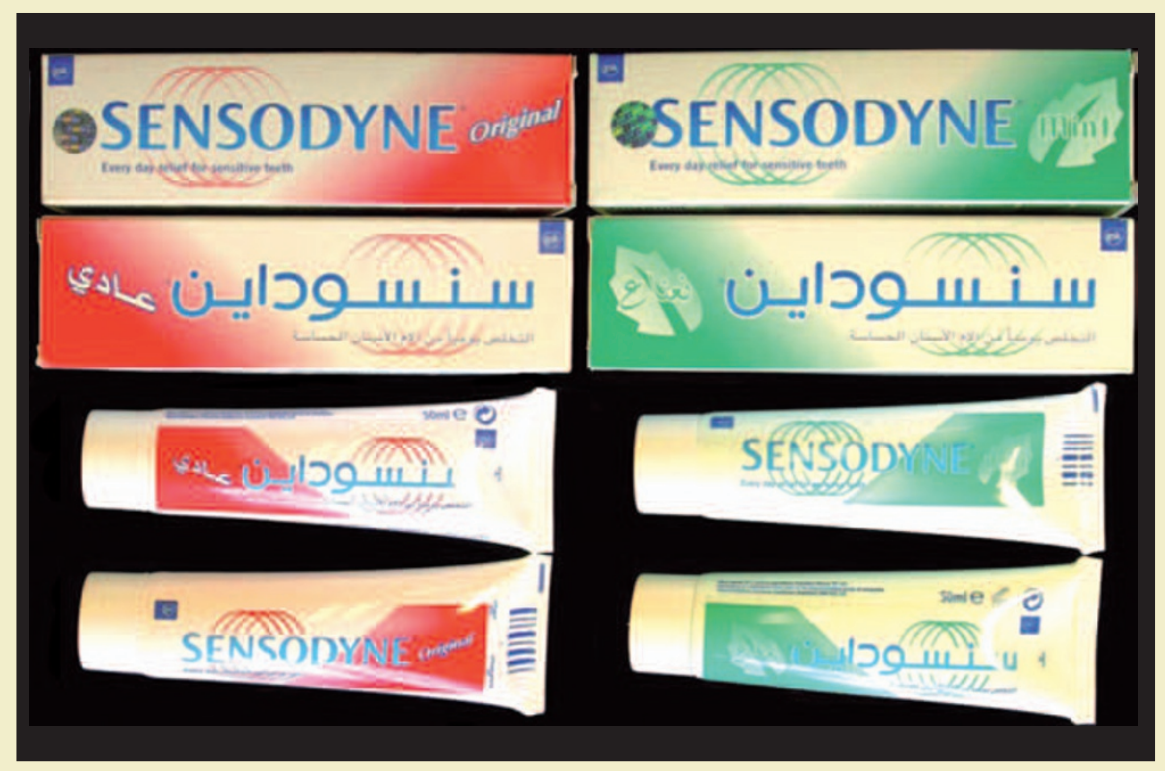

The fake packs are falsely labelled in English and Arabic

\section{New course}

The first practical training course for orthodontic therapists starts this month at Leeds Dental Institute. The course is the first 'hands on' dental course where the bulk of the training takes place outside a hospital setting. The 45 week course will start with a month of core training in Leeds Dental Institute and be completed either in an orthodontic practice or hospital department where the trainee therapists will work under the supervision of a specialist trainer.

Once the therapists have completed the course they will sit an examination for the Diploma in Orthodontic Therapy

\section{BDJ Archive}

BDA Member John Teesdale has a complete archive of BDJ copies from 1969- from the Royal College of Surgeons of England. They will then be able to take a full and active role in patients' treatment; taking impressions, fitting orthodontic bands, placing direct bonded attachments and ligating archwires.

Orthodontic consultant, Trevor Hodge, who set up the course with fellow consultant Simon Littlewood, explained, 'We work with highly skilled orthodontic nurses and recognised their lack of career progression. Given this fact, and coupled with the current shortage of orthodontic manpower, we felt it made sense to devise something that would benefit everyone.' Similar training courses are already planned at other centres in the UK.

1996 inclusive which he is offering to an individual, institution or organisation who would like them. Please contact John on 02084410788 if you are interested. 